\title{
The Brazilian National Policy for Regional Development and the RIDE-DF Management opposite the Governance vs Brasília's Metropolitan Area
}

Renata Callaça Gadioli dos Santos, Luiz Fernando de Macedo Bessa and Magda de Lima Lúcio

\section{OpenEdition}

\section{Journals}

Electronic version

URL: https://journals.openedition.org/echogeo/15072

DOI: $10.4000 /$ echogeo. 15072

ISSN: 1963-1197

Publisher

Pôle de recherche pour l'organisation et la diffusion de l'information géographique (CNRS UMR 8586)

Electronic reference

Renata Callaça Gadioli dos Santos, Luiz Fernando de Macedo Bessa and Magda de Lima Lúcio, "The Brazilian National Policy for Regional Development and the RIDE-DF Management opposite the Governance vs Brasília's Metropolitan Area", EchoGéo [Online], 41 | 2017, Online since 28 September 2017, connection on 01 August 2021. URL: http://journals.openedition.org/echogeo/15072 ; DOI: https://doi.org/10.4000/echogeo.15072

This text was automatically generated on 1 August 2021.

EchoGéo est mis à disposition selon les termes de la licence Creative Commons Attribution - Pas d'Utilisation Commerciale - Pas de Modification 4.0 International (CC BY-NC-ND) 


\title{
The Brazilian National Policy for Regional Development and the RIDE-DF Management opposite the Governance vs Brasília's Metropolitan Area
}

\author{
Renata Callaça Gadioli dos Santos, Luiz Fernando de Macedo Bessa and \\ Magda de Lima Lúcio
}

\section{AUTHOR'S NOTE}

This article was presented at International Conference of Public Policy, in Milan/July 2015.

\section{Introduction}

1 Two specific spatial public policies were on the current agenda of discussions in Brazil: The National Policy for Regional Development - PNDR and the National Policy for Urban Development - PNDU, also called Statute of the Metropolis/Law 13,039, of January $12^{\text {th }}$, 2015. These two policies seem to conflict when the management area is Brasilia, the Federal District, and its surrounding regions, the municipalities of the state of Goiás and Minas Gerais.

Brasilia-DF, in the year 2000, was officially classified a metropolis by the Brazilian Institute of Geography and Statistics - IBGE ${ }^{1}$. Its metropolitan nature was attributed solely for being a federal capital, with a very strong level of centrality. Even before that date, the actors of the Federal Capital, together with the actors from Goiás, sought after the right to institutionalize its metropolitan region and thus solve common everyday 
problems that began in the period following the inauguration of the Capital and that become worse each day.

Brasilia was considered a national metropolis in 2008 (REGIC, 2008). This definition was given based on the whole area of concentration of the population (ACP), defined as large urban patches of continuous occupation, characterized by the size and density of the population, the degree of urbanization and the internal cohesion of the area, given the shifts of the population for work or study.

4 According to REGIC, the network of Brasilia represents only $2.5 \%$ of the population - a relatively small amount for a network of a national metropolis - and concentrates $4.3 \%$ of the Gross Domestic Product (GDP). As highlighted by Ribeiro and Holanda (2015), it is important to note that this network has a high concentration in the Federal District, which represents $72.7 \%$ of the population and $90.3 \%$ of the GDP, in addition to having the largest income per capita among the other networks.

Despite being classified as a national metropolis, municipalities that make up the urban area of Brasilia are heterogeneous from a socioeconomic point of view, and are highly dependent on its 'headquarter'. In fact, the surrounding municipalities of the Federal District did not have the expected development with the installation of the capital, becoming extremely dependent on services and jobs located in the Federal District and consequently overloading the public system in the capital.

Until the 1988 Federal Constitution, the institutionalization of metropolitan area was an exclusive responsibility of the Union (Highest Federal-Level Government Representation). Now, in the same state municipalities can group together and integrate the organization, planning and execution of public functions of common interest. The legislation imposed, however, that states could only create within its political-administrative boundaries, which represented an impediment to both Brasilia and Goiás. The Union tried to solve the problem by creating RIDE ${ }^{2}$ DF-Entorno, within a regional and economic development policy and not within an urban development policy.

7 One of the instruments of territorial management that intends to manage and promote positive changes in the respective metropolitan space in question is The National Policy for Regional Development - PNDR, that launched in 2007, reinforced the existing three RIDES in Brazil as the only possibility for managing interstate cities. Although PNDR I is considered to be ineffective due to the lack of articulation between the old and new players in the territory and the lack of funding, What aspired its reformulation in a new PNDR, this second remains stagnant at the Federal Senate under the title of Projeto de Lei No. 375, 2015. It is considered that these legislations are part of the resumption of territorial planning and definition of public space policies in Brazil, this second phase built with a strong social management trait, through geographically decentralized conferences. The II PNDR, meanwhile, continues to prioritize and strengthens RIDE DFEntorno as a planning field for federal projects, in its article 12. Since 2015 in the Federal Senate its final implementation is questioned due the representativeness of its elaboration.

8 However, the metropolitan area of Brasilia, which claims to be built based on the Statute of the Metropolis, with its principles and metropolitan foundations, is governed by federal legislation (PNDR and RIDE DF and Entorno) in a justification that in an area 
composed by More than one federal state the neutral entity, the Union, should be its main manager and coordinator.

9 To understand this conflict of governance, understood in this way by several actors, it is necessary to understand how Brasília becomes a metropolis and in what context its metropolitan region is defined or accepted. The current context of such challenge begins at the origin and transfer of the Capital of the county to the Central area. To understand the governance challenge by the National Metropolis of Brasilia and the municipalities in the state of Goiás this article presents the origins and history of the problem, as well as the theoretical pillars which suggest readings and paths for the interpretation of public policies and the performance of local and national actors in different fields.

\section{The Source of Controversy}

In order to understand the existing controversy over how to manage the metropolitan space of Brasília and its respective instruments, which consequently leads us to an institutional conflict between federal government actors, researchers and local governmental actors, we must understand how Brasília became a metropolis. In this way, we will be able to understand the impediments and limits imposed on the federal capital in the definition of its metropolitan territoriality and its governance.

There were several reasons for transferring the Brazilian capital to the center part of the country. Until the early 1960s, the Federal Capital was in the State of Rio de Janeiro. One of those reasons was the intention to promote the development of the Midwest region of the country, integrating it with other Brazilian regions in a clear effort to enable national development.

According to Farret (2010) the transfer of the Capital to the Brazilian Central Plateau can be characterized as a territorial policy that is configured as a "complex setting of programs and actions aimed towards the elimination of obstacles to the full socialization of space by the expanded production of capital". Brasilia then comes up with the contours of a pole for urbanization and coordination with other regions of the country. Born with metropolitan force, in a context of national inequalities, to promote not only regional but national development as well.

13 Factors such as the expansion and population growth, lack of city infrastructure for the socioeconomic changes, violence and disorderly installment of the territory strengthened the need of protection to the political, administrative and cultural character of the Federal Capital, since it was the Federal District of the country.

In order, not to replay in Brasilia the same problems of big cities at the time, its creators put to work a strong control of the production and consumption (use) of urban land. So, the government agencies tried to protect the urban design, the Pilot Plan, but the adopted protective measures have created unforeseen spatial vulnerabilities, such as the fragmented and premature expansion of the city, the emergence of a periphery population, even before the Pilot Plan was finished and the expulsion off its activity limits of entire populations that could 'disfigure' it. Un financial fund, created in 1966, was established to promote the development of capital and its surroundings, preserving it from the ills of a rapid and unplanned urban growth. After that, the issue of municipalities that neighbor the Federal Capital came up again only in the first 
National Development Program (PND I), in 1972, when the national thinking of integration and regional development first started through plans and programs (Fernandes, 2001).

The IBGE (2007) published in 1972 one study with 9 metropolitan regions. The hierarchical urban order was the following: one Large Metropolis, one National Metropolis, four Metropolitan Regional Centers and four Macro-Regional Centers. Brasilia wasn't included. According to Paviani (2002), "at the time, Brasilia met the demographic characteristics, but did not hold major industries to be included in the list of metropolises then designed".

In 1975, PND II recognized the development of regional metropolises and established to Brasilia a geo-economic region with 22 municipalities of Goiás, as well as its development program (PERGEB).

In 1979, the Association of Municipalities Adjacent to Brasilia - AMAB was created to develop the metropolis that was being formed. It was the first formal no-governmental actor. AMAB is composed today by 22 municipalities.

In 1978, Brazil renewed the study for the country's division into urban functional regional areas. Such study was published only in 1987 with the title 'Regions of Influence of the Cities - REGIC'. In this federal document, Brasilia also was not considered a metropolis.

19 The rapid territorial expansion was marked by a lack of infrastructure and the creation of important socio-spatial inequalities. Brasilia and the surroundings cities are a territory with more than three and a half million habitants and with its dynamics is linked to an area considered a World Heritage Site by UNESCO since 1987.

In 1988, the Brazilian Constitution gave the basic permission to creating metropolitan areas to the state-level. They can institutionalize, manage, organize, plan and execute metropolitan public functions of common interest. However, it did not allow to Federal District or neighboring municipalities, located in different states, to compose a metropolitan area.

21 The third study of Influential Regions of the Cities-REGIC, in 1993, published only in the year 2000, was considered Brasilia at same level to the other national metropolitan areas and regional cities. However, it was still unable to establish its metropolitan region with the municipalities of Goiás.

In 1998, the Senate created the Economic Development Integrated Region of the Federal District and Surrounding Areas - RIDE DF-Surroundings, with 22 municipalities. The purpose of RIDE-DF is the region's economic development, especially in infrastructure and job creation. The figure below represents the composition of the RIDE with the Metropolitan Area of Brasilia highlighted (Figure 1). 
Figure 1 - Metropolitan Area Brasília and RIDE DF-Surroundings

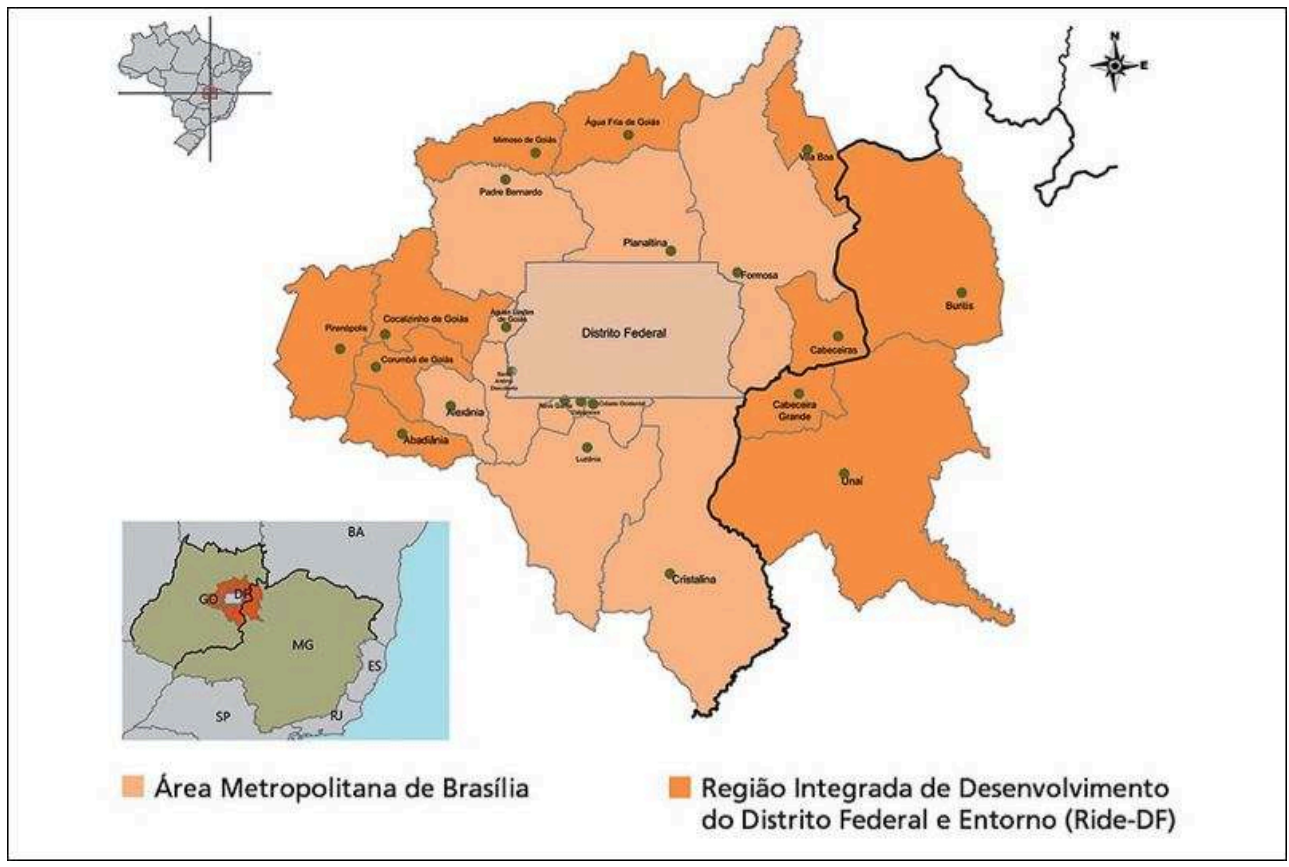

Source: CODEPLAN; GDF.

It is designed to traverse on tax incentives for the generation of employment and income, special credit lines, economic incentives and to attract investment in the productive sector. (Sampaio et al., 2013). The RIDE causes constant confusion when it tries to assume equivalence to a metropolitan area and it doesn't have the same goals or institutional arrangements. It was also not constituted by the same criteria of function diversification. "A metropolitan area usually has spatial concentration of population, economic activities, mass production and consumption." (Azevedo \& Alves, 2010). Resulting from this concentration demands for pavement, street lighting, schools, water supply and sanitation, environmental restoration, safety and health remain.

Only in 2007, in the new REGIC, Brasilia was elevated to a National Metropolis and is recognized as the third most important metropolis in the country, enhancing the wishes of metropolitan actors for a region of direct influence, called Metropolitan Area of Brasilia.

Through this chronology of political facts and decisions Brasília became a metropolis with a metropolitan space managed by regional development policies (PNDR and RIDE DF-Entorno), whose objectives were "to reduce regional inequalities and to activate the development potential of the Brazilian regions" (Resende et al., 2015, p. 30)

However, metropolitan management with the principles of managing and executing public functions of common interest, which solve daily problems of the metropolitan region, with collective definition between local actors of the size of their metropolitan territory and their problems in common, with basic principles of governance Metropolitan area defined by the Statute of Metropole, Law No. 13,089, of January 12, 2015, was not authorized to be practiced and executed by Brasília and Entorno.

The Union considers that the RIDE DF-Entorno is a metropolitan region. This controversy has provoked the indefinition of the denomination of the metropolitan 
space of Brasília, because it is understood that regional development policy does not have the same interests as a metropolitan development policy. For several actors, we cannot call the RIDE DF-Entorno metropolitan region and that ends by claiming a new metropolitan space that is intended to be called Metropolitan Area of Brasília, prohibited from being made official by the Metropolis Statute itself. In this way, the metropolitan governance of Brasília remains in a political limbo.

\section{The Social Field and Skills} Development.

This work was designed as a rehearsal on bringing together the theories of "social field", by Pierre Bourdieu, and "social skills", by Neil Fligstein. By agreeing with Bourdieu (2008), when the author says, "We cannot capture the deepest logic of the social world, but submerging into the particularity of an empirical reality", these theories will help us analyze the construction of a new National Policy for Regional

Both articulate their knowledge and arguments using field theory, but Fligstein uses it in public policy analysis by associating it with social skill theory. Bourdieu's theory (2011) considers the reading of the field as a social space, a system of relations between the actors involved where interests, power, conflicts, technical capacities, rules, principles and hierarchies intertwine in them. Bourdieu theorized several types of fields, each with its structures, rules, agreements, symbols and constructed by the participants, such as: economic, social, political, religious, scientific field.

For Fligestein, field theory has its origin in Bourdieu's own theory. The fields refer to situations in which organized groups of actors come together and develop their reciprocal actions face-to-face (Fligestein, 2001, p. 108). Therefore, the camps act to help reproduce the power and privilege of responsible groups and define the positions of the challengers. In its theoretical-methodological applicability the field or arena are spaces where local social orders are constructed, with existing resources and distributed unequally among the actors. These orders are basically articulated by the strength of their actors' social skills.

For Fligstein, social skill theory portrays a more sociological view of action and less of the rational choice of actors. It originates in "symbolic interactionism and is defined as the ability to induce the cooperation of others" (2001, p. 105). The author thus emphasizes the vital importance of the political action of the actors in the definition of public policies. Those are the actors, with their social skills, in the fields of action that are involved, those responsible for using strategies to convince or inculcate the other members of the field to choose or to act according to certain established.

In our specific case of study, we aim to apply the theories chosen in the field of public space policy planning in Brazil, based on two legal instruments outlined by the multiscale actors involved, their specific negotiation fields and the results that these choices are producing in the governance of the metropolitan area of Brasilia. These instruments are the PNDR and the PNDU (Statute of the Metropolis).

3 The PNDR establishes RIDE-DF and surroundings as a priority planning area. This region was created initially to allow an interstate planning between the Federal District and the municipalities of Goiás and Minas Gerais. However, another territorial configuration is historically pleaded by political and academic leaders of the Federal 
District and Goiás municipalities directly linked to the everyday life of the federal capital of Brazil. This region is called, since early 1980, Metropolitan Area Brasilia.

The management of these two areas depends heavily on instruments made available for public action, to organize the specific social relations between the government and its recipients. The instruments are also supported by a concept of regulation and always be inseparable from their actors (Lascoumes and Le Galés, 2004).

At this point, we associate to the actors the theory of social fields. Bourdieu argues that the actors' social positions, the habitus and their choices need to be considered due to a moment and social space given within each society (2008), and they ensure, in each field, their own reproduction (1996). According to Fligstein (2009), the fields act to reproduce the power and the privilege of the groups responsible.

Therefore, the actions may not have analyzed within themselves, but in their social, political and temporal context. We shall not analyze, however, the action of the actors, but the understanding and recognition of the various, and sometimes conflicting, social fields in which they operate.

Since the social field is a place of struggle and self-reproduction, maintenance and management tools settings will depend on the established relationships and the social skills created. Thus, we introduce the social skill theory by Neil Fligestein, which addresses the issue of institutions under the focus of the relationship between actors and social structures, specifically the sociological view called "social skills" that would be the ability of some actors in inducing the cooperation of others (2009) and conducting various local orders, motivating the actions in the fields.

The central point of the city and metropolitan areas management, therefore, lays in the relations and articulations of divergent interest and actions, that may be of economic, social or political nature, generating social inequality and non-unitary interests, for in them are the actors and non-homogeneous populations.

In addressing, thus, the governance we are talking not only of defining the instruments or the political action, but also of "collective action and the inclusion of new actors in discussions or negotiations and even collective decisions." (Lefèvre et al., 2013). Based on the social fields and the skills of the actors, instruments are either defined or rejected.

The conflict regarding the institutionalization of the territory of planning is reinforced by a regional development policy that prioritizes a planning region (RIDE-DFSurroundings) in contradiction to the interests of the local actors of a smaller territorial configuration.

41 The theories do not seek the resolution of conflict or controversy, but the understanding of the role of actors in the reproduction of the field and the maintenance of a specific situation. As a first approximation of theories to the theme we activate the understanding of the fields. In the future, it will be necessary to map the actors in each field, their actions and an accurate observation of the strategies that each one executed to convince other actors or groups of actors to perform or to agree with a specific position. In our case, the role of each actor and who they represent to prevent Brasilia and the municipalities of the states of Goiás and Minas Gerais, with whom the metropolis conforms metropolitan space can define and generate its territory. 


\section{The National Policy for Regional Development - PNDR}

PNDR I was established by Decree 6047/2007. It was understood that the existing inequalities in Brazil the weakened and prevented national integration. The PNDR I converged towards the current theoretical principles, namely: "a different vision on development as translated to planning initiatives aimed at exploiting endogenous potential of the regions" (MI, 2006) and valorization on economic growth.

Priority areas of focus of PNDR I were regions with economic weaknesses and stagnation, both defined by two specific criteria: the average household income and GDP growth per capita. Such methodology resulted in 4 micro-regions (high income: high household income per capita, regardless of dynamics; dynamic: average household income, but with important economic growth; stagnant: average household income, but with low economic and productive growth; and low income: low household income and absence of considerable economic dynamics).

The PNDR I, according to Senra (2009), did not have tools, resources or institutional bodies that would enable it to achieve its goals and did not have consensus in the Federal Govern. Since its launch, the Ministry of Integration, the agency responsible for it, had only its own resources for its implementation.

In this way, one of the main elements for the social skills of the actors could emerge and start the work of building political coalitions fell to the ground, namely: lack of resources and / or tools. These elements act as sources of power (Fligestein, 2001, p. 107). However, as a policy proposal for primary domain management of the Union, the fields of action for the implementation of the policy itself were also centralized. In this case, social skill could not even be a strong element in the articulation of fields and actors that would promote territorial governance. In reading Alves and Neto (2014, p. 316), the fragility of the PNDR I was, among other factors, its exclusive link in a single instance of strategic coordination in the federal government, which eventually caused an absence of effective instances of pacts and coordination.

The idealized management tools, such as the National Regional Development Fund, the National Council of Regional Development and the Chamber of Regional Development Policies never left the drawing board. It became impossible to recognize PNDR as a government policy (BRAZIL, 2013).

In the years 2012 and 2013, through conferences in the Brazilian states and in Brasilia, the principles and guidelines for the new National Policy for Regional Development were defined (PNDR II), which still has its bill moving in the Brazilian Congress.

The new National Policy for Regional Development - PNDR II is within the scope of social democratization public policies, national integration and overcoming of regional inequalities. The difference between them is less because of the form and methodology of selection of the priority areas and more by the attempt of insertion of new social actors. Principles such as transescalarity, multidimensionality and the transversality of policies provide us with a view of the difference between the two proposals for territorial governance instruments.

The innovative element in the methodology for choosing eligible microregions does not refer to a strong element to be considered as a generator of the problems experienced by the metropolitan space of Brasilia or the solvent of regional inequalities in Brazil. The micro-regions eligible for application of the new PNDR II differ in each main 
objective of the legislation, but, in general, are all related to the Household Income Per Capita/RDPC, like PNDR I.

50 A focus of its rewriting is social participation. Even if there is criticism on the possibility of developing democratizing public policies, those have been instrumental in rebuilding the public nature of governments in societies increasingly plural, open, complex, informed and participatory.

51 These are the specific objectives:

- Promoting the convergence of the level of development and quality of life between and within the regions of Brazil and equity in access to development opportunities in regions with low socioeconomic indicators;

- Ensuring regional competitiveness and the generation of employment and income in regions with declining population and high rates of emigration;

- Promoting value addition and economic diversification in regions with strong expertise in the production of agricultural and mineral commodities;

- Consolidating a polycentric network of cities, contributing to the deconcentrating and interiorization of development of regions and the country, strengthening centralities in different geographical scales.

\section{The Social Fields and the Instruments in PNDR}

Regarding the development on a local scale, its model was based on the development of endogenous potentialities, which according to Boisier is considered a positive collective mental attitude (2004) and the knowledge of their own potentialities by the local community. It is the compromise to the population in the definition of relevant policy options pertinent to each territorial scale. The PNDR II comes, this way, to increase popular participation in the definition of local and regional development processes as well as in the governance of public policies.

For Bourdieu (2008, p. 18), local social orders are called fields, "groups of actors that come together and develop their reciprocal actions face-to-face." According to Fligstein (2007, p. 64), the fields act to reproduce the power and privilege of the responsible groups. In social field theory, Bourdieu also argues that the social positions of the actors, the habitus and their choices need to be considered because of a determined social moment and space within each society.

Analyzing the PNDR I and PNDR II, the latter still in progress, we face the possibility of the clear existence of social fields in the reproduction of their proposals at different geographical scales (national, macro-regional and local) as well as their difficulties in implementation, through its institutional arrangements at different times. The chart below attempts to demonstrate the social fields of PNDR I, as well as its main instruments. 
Figure 2 - Courses and instruments

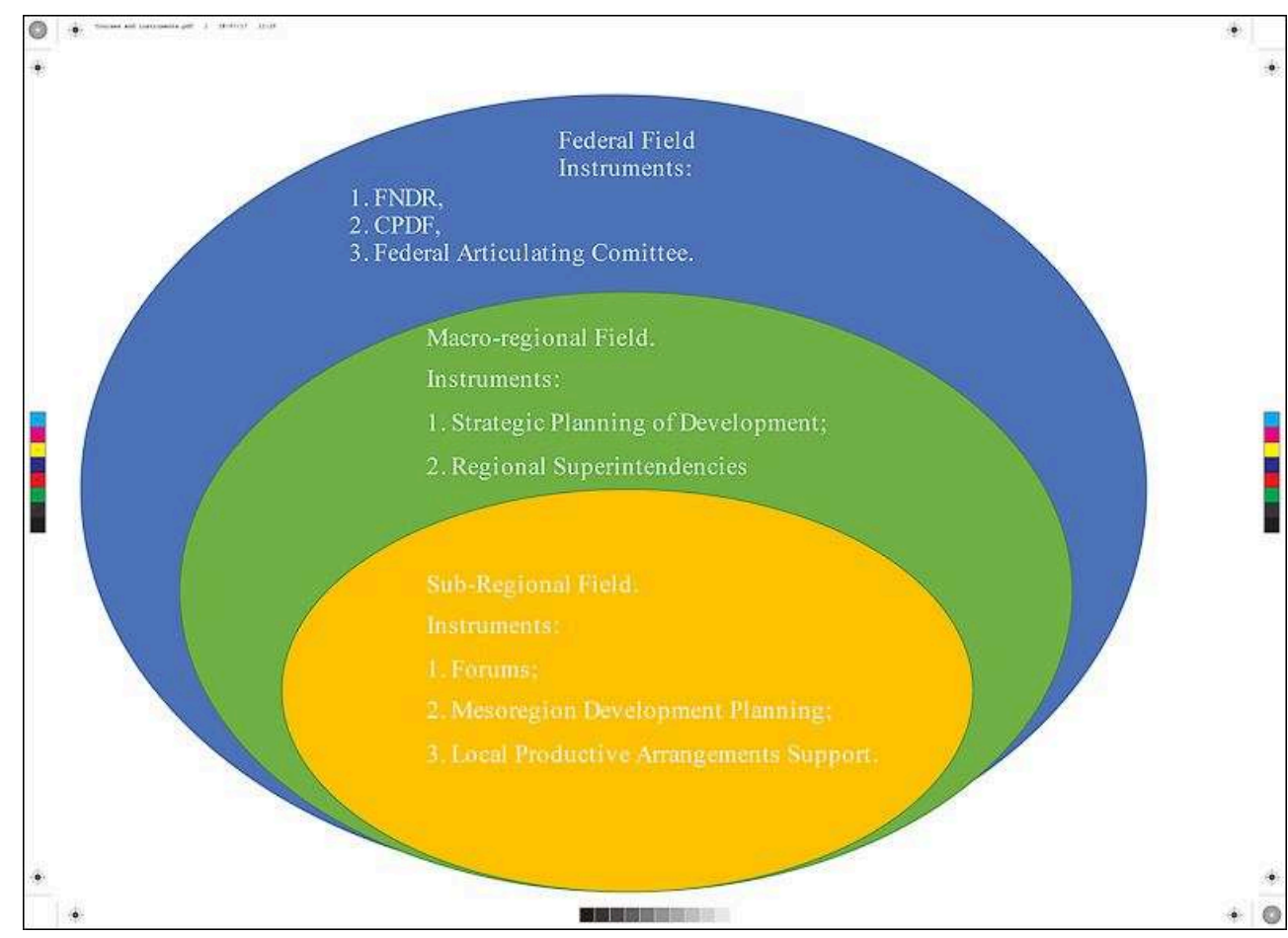

Source: authors.

The PNDR I articulated on the competitiveness principles of regional areas and ended up favoring fragmentation. The absence of its pillars, namely the National Fund for Regional Development and the Chamber of Regional Development Policies /CPDR, reflected the lack of "rules for interaction and distribution of resources that would act as a source of power and reproduction of social orders." (Fligstein, 2009). In mid-2012, the CPDR was reactivated, and intended to be a key role in PNDR II.

The PNDR II, of collective design through conferences, aims to be a more equitable access to goods and essential local and not localism public services, for it has as a premise the relationship with the regional economic and social development. The relationship between territorial scales is intended to be effective by the "articulated construction of development agendas at various scales, with the participation of various federal entities and civil society, presided by a national agenda" (BRAZIL, 2013).

Fligstein addresses the issue of institutions under the focus of the relationship between actors and social structures, more specifically in the sociological view called "social skill", which would be the ability of some actors to induce the cooperation of others. (2009, p. 62) and in the conduct of several local orders, motivating the actions in the fields. The PNDR II, however, is still a law project that has remained in the National Congress since 2014. In the current political scenario of Brazil it seems that it will remain there forgotten. The rules and resources remain concentrated in the state actor, making it impossible for actors to carry out their main task in the fields, namely: to promote strategic policy interactions and to reproduce the orders of the fields that are most skillful. 


\section{The RIDE DF-Surrounding Areas as Priority Area II PNDR}

In rewriting the PNDR in progress, bordering tracks of the Brazilian territory, the semiarid regions and RIDE-DF are considered priority areas. According to Alves and Neto (2014), each of one has regional problems. The RIDE-DF-Surroundings has as its characteristics a high degree of inequality, being a point of the country's logistics integration, besides being an urban conglomerate or conurbation ${ }^{3}$ with metropolitan characteristics.

To manage this region a multidisciplinary organization was established: The Administrative Council of the Integrated Development Region of the Federal District and surrounding areas - COARIDE. Its composition, however, is almost entirely from the federal level. of the 22 municipalities that make it up, only one representative sits on the Council, as Figure 3 shows the fields and actors involved in COARIDE.

Figure 3 - Organization of COARIDE Actors

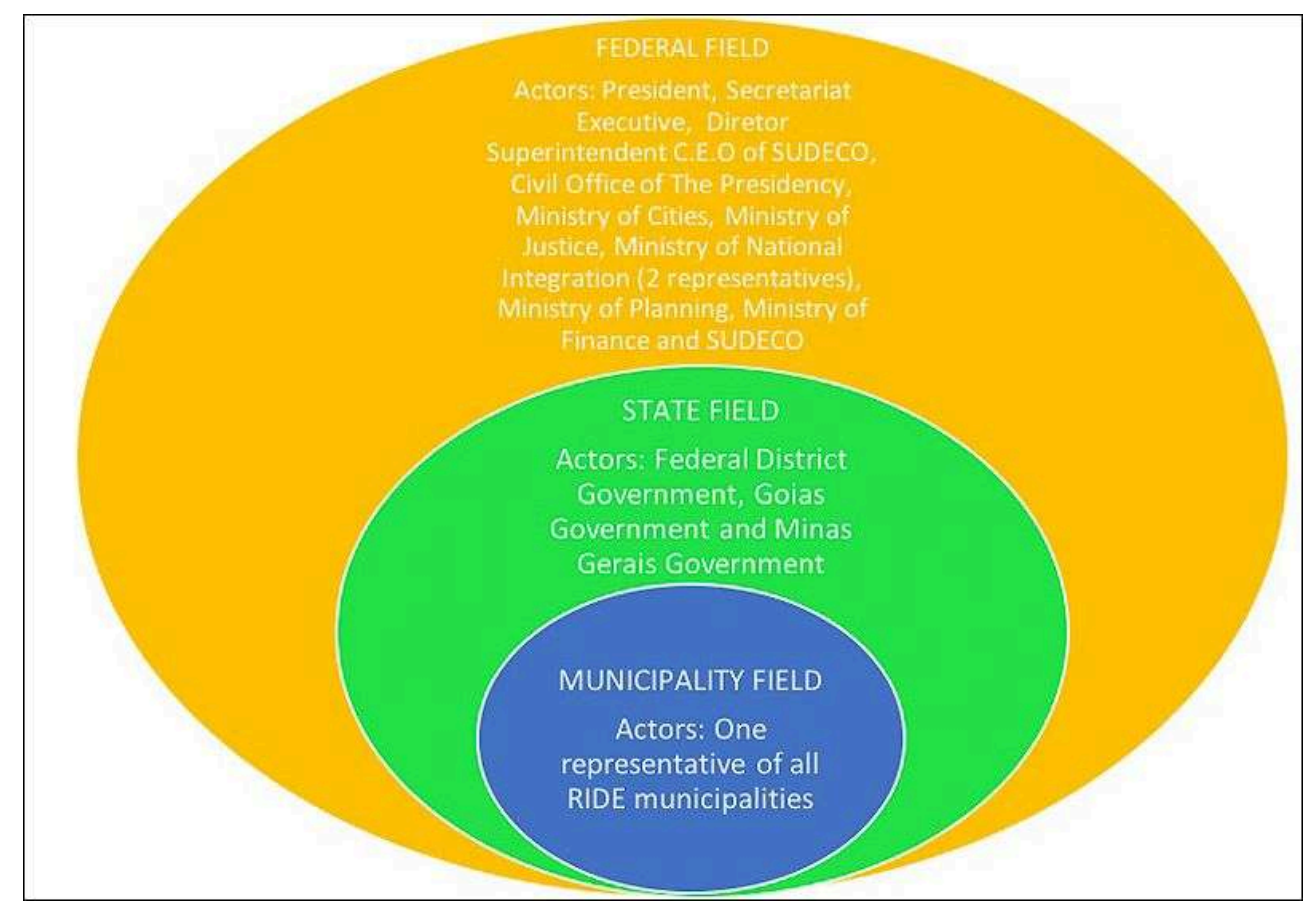

Source: authors.

Despite the COARIDE having an interest in organizing common public services, its actions have not effectively moved on from the creation of work groups in 2011, and there was no involvement with society. The focus of COARIDE remained in federal public policies developed by the Growth Acceleration Program - PAC in the areas of urban and semi-urban mobility, public safety, social and productive inclusion, sanitation and the World Cup (Sampaio et al., 2013). 


\section{National Policy for Urban Development - PNDU - Guidelines to the Statute of Metropolis}

61 The Statute of Metropolis, instituted in January 2015, by the Law 13,089, has an objective to create rules for the shared governance of public functions of common interest - FPIC ${ }^{4}$ in adjacent municipalities, by promoting 'interfederative' governance.

62 While the Union oversaw the metropolis during the military government, Brazil had only nine metropolises. From the Federal Constitution of 1988 and the growing urbanization process of the country, polarized cities grew in number, as well as the number of metropolitan regions. Today are about 65 established ones and 3 RIDEs.

63 It was hoped, however, that Brasilia could be included to institutionalization of the metropolitan territory that exists but has no political existence, as the Metropolitan Area of Brasília - AMB. The justification for such exclusion was that a single municipality could not be considered a metropolis, which meant Brasilia was prevented from being one. Such position is contrary to IBGE's legal document, REGIC, which since the year 2000 declares Brasilia as a metropolis of great political and administrative importance. Another argument is based on the fact that the Federal Constitution determines, in its article 25, that a metropolitan region is to be formed by groups of municipalities and Brasilia cannot be considered one, leaving it to be regionally articulated to RIDE and to the public policies defined by it.

The legal articles that could have allowed the Metropolitan Area of Brasilia (AMB) to become institutionalized territory were, however, revoked by one of the actors of the process, pertaining to the federal field. However, Article 4 of the same law allows for a metropolitan area or urban area involving municipalities belonging to more than one state, if they are formalized through the effectiveness of complimentary laws by each legislative assembly of the states involved. This perspective solves the issue of formalization of Metropolitan Brasilia, but it continues to require that the two governments establish an ongoing dialogue as well as a Plan of Integrated Urban Development.

65 The Statute of Metropolis is not considered a solution for the matters regarding metropolitan governance, since issues such as financing and integrated planning of sectoral policies are still pressing in the areas of management. But given the context, it is certainly a first step towards the management of such complex, politically fragmented areas and their various actors, also of different management scales. Management tools in such a complex context like this are also needed.

66 As for the instruments, the Statute of Metropolis defines, as for the shared management of FPIC 10 typologies, including: public consortia, public funds, cooperation agreements, contracts management and public-private and interfederative partnerships and the Integrated Urban Development Plan (PDUI), which has the outmost discretion to the enactment of a metropolitan area.

When it comes to the actors, the Statute of Metropolis clearly defines the role of the Union in Article 13: The Union will support initiatives by states and municipalities aimed at inter-federative governance, reinforcing once again the decentralization of power as a solution for national problems, because Metropolis is an inter-federative and state-level interest. 

up being forced to find other ways to promote the life of the populations that daily share transportation, hospitals, sanitation, basic education and higher education schools.

The PNDR follows the line of regional economic development, with strong application of federal policies in the Brazilian territory, even if its new proposal seeks to articulate a larger number of actors. Its second proposal, based on objectives, still brings intentions as regional competitiveness based on the promotion of economic diversification. It has RIDE DF and Entorno as a priority area, although Brasilia alone does not enter the list of priorities. The PNDR intends to promote the development of RIDE through the fields of action of the actors that do not favor the diversity and representativeness of civil society, as proposed by the PNDR. Thus, if there is no change in RIDE legislation, the PNDR itself will have a blind proposal for the metropolitan area of Brasília.

In turn, the Statute of Metropolis seeks to articulate, in partnership with the entities that make up the metropolitan territory, the solution of common problems, also called public functions of common interest, these also collectively chosen, agreed among the actions. Its institutional arrangements seek multidimensional action and the intersectoriality of policies. In this structure of action the social ability to reproduce fields is indispensable, without it, the democratic character of metropolitan governance will not occur.

71 As we can see, Brasília and its metropolitan area is managed by legislation and instruments that, despite being named metropolitan (as RIDE calls itself), its main focus is the reduction of economic inequalities between regions and the generation of competitiveness Through federal projects, which does not satisfy the interests of local actors. On the other hand, the Statute of Metropolis, which is closer to the intention of territorial management than the ones intended by the local actors, also did not provide space for such governance of the metropolitan area of Brasília. The Metropolis Statute considered that the management instruments of this area should be borne by the Union. We can see that the local actors who seek to formalize a new metropolitan management size and limit were not able to articulate actors from other fields to cooperate with their ideals.

\section{Conclusion}

72 Two spatial policies and an area crying out for better political and administrative connections to solve everyday problems of a region with metropolitan characteristics. Brasilia and the neighboring municipalities all have metropolitan characteristics. The field of urban politics and the field of Brazilian development, with almost the same actors, given the intersectoriality of the theme, try not to allow the instrument of one field to annul the instrument of another. They seek to lead them to be complementary.

Over the years many actors were coming together for the construction of a metropolis Brasília. As Galés (2014) points out, "la métropole se construit comme le fruit d'une intelligence collective". But, in consequence, oppositions and disagreements arise impacting on the exercise of consensus whenever possible.

EchoGéo, 41 | 2017 

federal capital, continue to re-articulate their actors, here defined as "social actors skilled in challenging groups" (Fligenstein, 2001, p. 117) to promote the management and execution of public functions of common interest decided in a consensual and collective manner among the local actors.

\section{BIBLIOGRAPHY}

Alves A. M., Rocha Neto J. M., 2014. A nova Política Nacional de Desenvolvimento Regional - PNDR II: entre a perspectiva de inovação e a persistência dos desafios. Revista Política e Planejamento Regional (PPR), Rio de Janeiro, vol. 1, $\mathrm{n}^{\circ} 2$. Disponível em: http://www.revistappr.com.br/artigos/ extra/5525776c88b67.pdf. Acesso em: 15 de abril de 2015. 
Azevedo H. P. L, Alves A. M., 2010. RIDE - Por que criá-las? Revista Geografias, Belo Horizonte, vol. 06, n 02. Disponível em: http://www.cantacantos.com.br/revista/index.php/geografias/ article/view/119/117. Acesso em: 05 de março de 2015.

Boisier S., 1996. Em busca do esquivo desenvolvimento regional: Entre a caixa preta e o projeto político. Revista Planejamento e Políticas Públicas, nº 13, p. 111-147, junho.

Boisier S., 2004. Desarollo territorial y descentralización. El desarollo en el lugar y en las manos de la gente. Revista Eure, vol. XXX, ํㅜ 90. Santiago del Chile, septiembre.

Bourdieu P., Passeron J.-C., 2012. A Reprodução: Elementos para uma teoria do Sistema de ensino. $5^{\mathrm{a}}$ edição. Petrópolis, Rio de Janeiro: Editora Vozes.

Bourdieu P. 2008. Razões práticas: sobre a teoria da ação. São Paulo, Papirus.

BRASIL, 1988. Constituição da República Federativa do Brasil de 1988. Brasília, Assembleia Nacional Constituinte.

BRASIL, 2007. Decreto no $\mathbf{0} .047$, de 22 de fevereiro de 2007. Institui a Política Nacional de Desenvolvimento Regional (PNDR) e dá outras providências. Brasília, Disponível em: http:// www.planalto.gov.br/ccivil_03/_ato2007-2010/2007/decreto/D6047.htm. Acesso em: 25 de março de 2014.

BRASIL, 2012. I Conferência Nacional de Desenvolvimento Regional: texto de referência. Brasília, DF, Ministério da Integração Nacional.

BRASIL, 2015. Lei 13.089. Estatuto das Metrópoles. Brasília, Disponível em: http:// www.planalto.gov.br/ccivil_03/_Ato2015-2018/2015/Lei/L13089.htm. Acesso em: 15 de janeiro de 2015

Farret R. L2010. O Estado, a questão territorial e as bases da implantação de Brasília. In Paviani A. (org.), Brasilia, ideologia e realidade: espaço urbano em questão. Brasília:, Editora Universidade de Brasília.

Fernandes D. M., 2001. Notas sobre os Programas para a Região Geoeconômica de Brasília. In Hogan D. J. et al (org.), Migração e Ambiente nas Aglomerações Urbanas. São Paulo, Unicamp. Disponível em http://www.nepo.unicamp.br/textos/publicacoes/livros/migracao_urbanas/ 02pronex_03_Notas_sobre_Programas.pdf. Acessado em 17 de janeiro de 2015.

Fligstein N., 2007. Habilidade Social e Teoria dos Campos. RAE, São Paulo, vol. 47, nºo 02, p. 61-80, Abril/Jun.

Fligstein N., 2009. Habilidade Social e Teoria dos Campos. In Martes A.C.B. (org), Redes e sociologia econômica. São Carlos, EdUFSCAR.

IBGE - Instituto Brasileiro de Geografia e Estatística- Ministério do Planejamento, Orçamento e Gestão, 2008. Região de Influência das Cidades (REGIC). Rio de Janeiro, IBGE.

Lascoumes P., Le Galès P. (dir.) 2004. Gouverner par les Instruments. Paris, Presses de la Fondation Nationale des Sciences Politiques.

Lefevre C., Roseau N., Vitale T., 2013. Les défis de la gouvernance métropolitaine. In Lefevre C., Roseau N., Vitale T., De la Ville à la Métropole. Les défis de la gouvernance. L'œil d'or, p. 21-34.

Les Galès P., 2011. Le Retour des Villes Européennes. Paris, Presses de Sciences Po.

Paviani A. 2002. Brasília, metrópole incompleta. Minha Cidade, São Paulo, ano 02, n 024.01, Vitruvius, jul. 2002 http://www.vitruvius.com.br/revistas/read/minhacidade/02.024/2058 
Resende G. M., 2015. Fatos Recentes do Desenvolvimento Regional no Brasil. Texto para discussão/Instituto de Pesquisa Econômica Aplicada, Brasília, Rio de Janeiro, Ipea.

Ribeiro R. J. da C., Holanda F., 2015. A Configuração da Área Metropolitana de Brasília. In Ribeiro R. J. da C. et al (org.), Brasília: transformaçôes na ordem urbana. Rio de Janeiro, Letra Capital.

Sampaio C. da S. et al., 2014. O espaço metropolitano do Distrito Federal: uma nova RIDE. In Costa M. A., Pantoja I., Marguti B., O Relatos e Estudos de Caso da Gestão Metropolitana no Brasil. Brasília, IPEA.

Sampaio C. da S. et al., 2013. Arranjos institucionais de gestão metropolitana: O caso da RIDE-DF. In Costa M. A., Tsukumo T. L. (org.), 40 anos de regiões metropolitanas no Brasil. Brasília, IPEA.

Senra K. V., 2009. Políticas federais de desenvolvimento regional no Brasil: uma análise comparada dos períodos pós-guerra (1945-1964), pós-golpe militar (1964-1988) e pós-Constituição Federal de 1988 (1988-2009). Dissertação (Mestrado em Geografia) - Universidade de Brasília, Brasília.

\section{NOTES}

1. The preparation of the Influence Areas of Cities (REGIC), by IBGE, aimed at building a national framework to support the planning and management of Brazilian municipalities, regarding economic production, existing social relations and spatiality generated by them. In it, the hierarchy of urban centers was divulged, divided into five levels: (i) Metropolis; (ii) regional capital; (iii) sub-regional center; (iv) Zone Center; (v). Brasilia, along with Rio de Janeiro and Sao Paulo, presents itself as a first-level management of territory. (REGIC 2008)

2. Integrated Region for Economic Development of the Federal District and Surrounding areas.

3. Conurbation: urban territorial unit constituted by 2 (two) or more clusters of neighboring municipalities, characterized by functional complementarity and integration of geographical, environmental, socioeconomic and political dynamics. Definition used by the Statute of the Metropolis and IBGE.

4. A public service of common interest is a public policy or action that only one municipality has difficulty in performing or even in being feasible, causing negative impacts to other neighboring municipalities.

\section{ABSTRACTS}

The Brazilian National Policy for Regional Development - PNDR was established by Decree $6047 / 2007$. However, many public managers claim that it has yet to reach a status of State Policy or a political or a federal consensus able to promote a non-fragmented and even growth of regions. The discussion is now around the institutionalization of a new policy, PNDR II, which remains in efforts to reduce regional inequalities and seeks to remedy shortcomings in the first proposal. Despite the proposal to update the legislation in question, the metropolitan territory of Brasilia, also defined by federal legislation and called RIDE DF and Entorno - Integrated Region of Development of the Federal District and Entorno is identified as a priority area of planning and management, but its metropolitan governance continues to generate conflicts and maintain 
inequality in its peripheral areas. To contribute to the debate of possible reach of PNDR in the management of important and complex city, which is also the federal capital, and its respective metropolitan area, we suggest a theoretical and methodological analysis of the urban governance model. Throughout the analysis, we will demonstrate the relationship between PNDR I and II with the - RIDE-DF and Entorno, a proposal for territorial management of the Federal District of Brazil and its urban agglomeration. In this context, the objective of this article is to analyze the instruments proposed by the New National Policy for Regional Development in the face of the challenge of ensuring better regional or metropolitan governance for the RIDE DF e Entorno.

La politique nationale brésilienne pour le développement régional - PNDR a été créée par le décret 6047/2007. Cependant, de nombreux gestionnaires publics affirment qu'elle n'a pas encore atteint un statut de politique d'État ou un consensus politique ou fédéral capable de promouvoir une croissance non fragmentée et équilibrée des régions. La discussion porte maintenant sur l'institutionnalisation d'une nouvelle politique, le PNDR II, qui continue de réduire les inégalités régionales et cherche à remédier aux insuffisances de la première proposition. Malgré la proposition de mise à jour de la législation en question, le territoire métropolitain de Brasilia, également défini par la législation fédérale et appelé RIDE DF et Entorno - Région intégrée de développement du District fédéral et de ses environs, est identifié comme un domaine prioritaire de planification et de gestion, mais sa gouvernance métropolitaine continue de créer des conflits et de maintenir l'inégalité dans ses zones périphériques. Pour contribuer au débat sur la portée possible du PNDR dans la gestion d'une ville aussi importante et complexe, qui est aussi la capitale fédérale, et ses régions métropolitaines respectives, nous proposons une analyse théorique et méthodologique du modèle de gouvernance urbaine. Tout au long de l'analyse, nous démontrerons la relation entre PNDR I et II et la - RIDE-DF et Entorno, une proposition de gestion territoriale du District fédéral du Brésil et de son agglomération urbaine. Dans ce contexte, l'objectif de cet article est d'analyser les instruments proposés par la nouvelle politique nationale pour le développement régional face au défi d'une meilleure gouvernance régionale ou métropolitaine pour le RIDE DF et Entorno.

\section{INDEX}

Mots-clés: gouvernance, développement régional, Brasilia, instrument de politique publique Keywords: governance, regional development, Brasilia, public policy instrument

\section{AUTHORS}

\section{RENATA CALLAÇA GADIOLI DOS SANTOS}

Renata Callaça Gadioli dos Santos, renatagadioli@gmail.com, Geographer, Master in Geography from the University of Brasilia/Brazil. PhD Student at Université de Paris 7 - France (Geography of Development) and at University of Brasília - Brazil (Development, Society and International Cooperation - PPGDSCI/CEAM/UnB). NEUR researcher/CEAM and the Laboratory of Population and Development CEAM/UnB.

\section{LUIZ FERNANDO DE MACEDO BESSA}

Luiz Fernando de Macedo Bessa, lfmbessa@gmail.com, Doctor of Human Geography and Space Organization from the University of Paris 1, Coordinator of the Center of Urban and Regional Studies at the Multidisciplinary Center for Advanced Studies at the University of Brasília - NEUR/ 
CEAM, Professor of the Department of Public Policy and Management and of the Program of PostGraduation in Development, Society and International Cooperation - PPGDSCI/CEAM/UnB.

\section{MAGDA DE LIMA LÚCIO}

Magda de Lima Lúcio,magdadelimalucio@gmail.com, Master and Doctor in Sociology from the University of Brasilia/Brazil. Coordinator of Department of Public Policy and Management/UnB. Professor of the Program of Post-Graduation in Development, Society and International Cooperation - PPGDSCI/CEAM/UnB. 